\title{
Dynamic Strain-Induced Ferrite Transformation during Hot Compression of Low Carbon Si-Mn Steels
}

\author{
Ming-Hui Cai ${ }^{1, *}$, Hua Ding ${ }^{2, *}$ and Young-Kook Lee ${ }^{1}$ \\ ${ }^{1}$ Department of Materials Science and Engineering, Yonsei University, Seoul 120-749, Korea \\ ${ }^{2}$ School of Materials and Metallurgy, Northeastern University, Shenyang 110819, P. R. China
}

\begin{abstract}
The dynamic strain-induced transformation (DSIT) of austenite to ferrite was investigated under different undercooling conditions using three low carbon Si-Mn steels. The undercooling of austenite $(\Delta T)$ was controlled by varying the cooling rate between austenitization and deformation temperatures. Uniform DSIT ferrite grains $(\sim 2.3 \mu \mathrm{m})$ were produced at a relatively high deformation temperature above $840^{\circ} \mathrm{C}$ using a low carbon high Si steel $(0.077 \mathrm{C}-0.97 \mathrm{Mn}-1.35 \mathrm{Si}$, mass $\%)$ in connection with a larger $\Delta T$. The critical conditions for DSIT were determined based on the flow stress-strain curves measured during hot compression tests. Influence of deformation temperature on DSIT of low carbon Si-added steel was also discussed. [doi:10.2320/matertrans.M2011117]
\end{abstract}

(Received April 19, 2011; Accepted June 28, 2011; Published August 10, 2011)

Keywords: low carbon steel, dynamic ferrite transformation, grain refinement, hot compression, silicon addition, undercooling of austenite

\section{Introduction}

The ferrite grain refinement has attracted considerable interests from the steel industry because of its unique role in simultaneously improving strength and toughness of steels. In recent years, several thermomechanical controlled processing (TMCP) routes have been developed to produce ultrafine ferrite grains in hot-rolled microalloyed or plain low carbon steel strips. ${ }^{1-4)}$ The dynamic strain-induced transformation (DSIT) has been reported to be one of the most promising fabrication processes for ultrafine-grained (UFG) metallic materials because of its simplicity and efficiency in grain refinement with a low cost. ${ }^{1,5-8)}$ Grain refinement by the DSIT process is strongly dependent on the chemical composition of steels, prior austenite grain size (AGS), undercooling of austenite $(\Delta T)$, and rolling conditions such as temperature, thickness, and strain rate. ${ }^{9)}$

More recent studies in plain low C-Mn steels have suggested that DSIT can be provoked by imposing a heavy reduction above $80 \%$ as well as a low rolling temperature below $770^{\circ} \mathrm{C}^{1,5,6)}$ However, there still exist limitations to the application of low-temperature heavy deformation for standard industrial mills. Therefore, it would be of practical importance to investigate the possibility of DSIT occurring at higher temperatures, for example, above $830^{\circ} \mathrm{C}$.

To achieve the DSIT ferrite at a relatively higher rolling temperature, two factors need to be considered: (i) increasing the thermodynamic equilibrium temperature $\left(\mathrm{Ae}_{3}\right)$ and the transformation start temperature of austenite to ferrite $\left(A r_{3}\right)$; (ii) inhibiting austenite recrystallization before DSIT ferrite nucleation at higher temperatures. Hong et al. ${ }^{7)}$ and Eghbali et $a l .{ }^{8)}$ investigated the ferrite grain refinement using low carbon $\mathrm{Nb}$-microalloyed steels in connection with DSIT, showing that $\mathrm{Nb}$ addition delays austenite recrystallization, allowing the DSIT ferrite to form at a relatively high rolling temperature. However, there is no literature concerning the ferrite grain refinement by the DSIT process using plain low

*Corresponding author, E-mail: hding@263.net; caiminghui@yonsei.ac.kr carbon Si-added steels. In our previous study, ${ }^{10)} \mathrm{Si}$ was considered to decrease the difference in strength of ferrite and bainite by strengthening the ferrite matrix, improving simultaneously tensile strength and stretch-flangeability of steels. In addition, $\mathrm{Si}$ addition not only increases $\mathrm{Ae} e_{3}$ and $\mathrm{Ar} r_{3}$ temperatures ${ }^{11)}$ but also delays austenite recrystallization, ${ }^{12)}$ probably allowing DSIT to occur at a relatively higher temperature. Until now, the combined effects of $\mathrm{Si}$ and undercooling of austenite on DSIT in plain low carbon steels has not received much attention.

In the present study, therefore, hot compression tests were carried out on three plain low carbon $\mathrm{Si}-\mathrm{Mn}$ steels under different undercooling conditions using a Gleeble-2000 thermomechanical simulator. The combined effects of $\mathrm{Si}$ and $\Delta T$ on DSIT were mainly investigated through microstructural characterization and mechanical behavior analyses. The undercooling of austenite was designed by applying various cooling rates between austenitization and deformation temperatures. Based on the flow stress-strain curves measured during hot compression tests, the critical conditions for DSIT were determined. The research can provide a theoretical basis for fabricating an UFG ferrite and bainite dual-phase structure with both high strength and excellent stretch-flangeability in hot-rolled plain low carbon steel strips.

\section{Experimental Procedures}

\subsection{Materials and equipment}

Three plain low carbon steels were prepared as vacuummelted $50 \mathrm{~kg}$ ingots, followed by hot forging to produce small plates measuring $30 \times 100 \times 100 \mathrm{~mm}^{3}$. Their chemical compositions are shown in Table 1 . In addition, their $A e_{3}$ temperatures in Table 1 have been obtained from ThemoCalc using TCFE5 database.

The hot-forged plates were austenitized at $1150^{\circ} \mathrm{C}$ for $2 \mathrm{~h}$, and then were hot-rolled to $10 \mathrm{~mm}$ thick followed by air cooling to room temperature. The microstructure of as hotrolled samples consisted of near-equiaxed ferrite grains of 
Table 1 Chemical compositions, $A e_{3}$ temperature, and prior austenite grain size (AGS) of the steels studied in this study (mass\%).

\begin{tabular}{cccccccc}
\hline Steel & $\mathrm{C}$ & $\mathrm{Si}$ & $\mathrm{Mn}$ & $\mathrm{P}$ & $\mathrm{S}$ & $\mathrm{Ae}_{3}\left({ }^{\circ} \mathrm{C}\right)$ & $\mathrm{AGS}(\mu \mathrm{m})$ \\
\hline No. 1 & 0.078 & 0.50 & 0.97 & 0.004 & 0.002 & 866 & $60 \pm 15$ \\
No. 2 & 0.077 & 1.35 & 0.97 & 0.004 & 0.007 & 912 & $25 \pm 10$ \\
No. 3 & 0.077 & 0.56 & 1.43 & 0.005 & 0.003 & 851 & $55 \pm 10$ \\
\hline
\end{tabular}

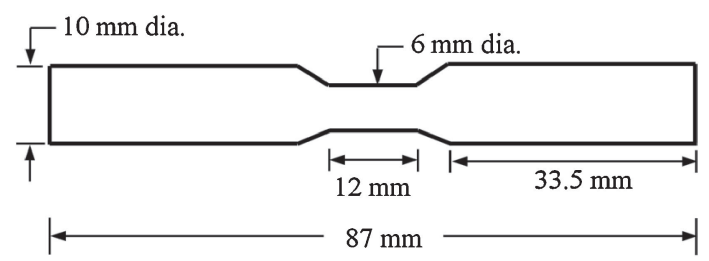

Fig. 1 Specimen geometry for hot compression tests using a Gleeble-2000 simulator.

more than $85 \%$ with an average grain size of approximately $20 \mu \mathrm{m}$ and pearlite.

Uniaxial compression tests were conducted under a high vacuum $\left(1.3 \times 10^{-4} \mathrm{~Pa}\right)$ using a Gleeble-2000 thermomechanical simulator (Dynamic Systems, Inc., Poestenkill, $\mathrm{NY}$ ) that can provide precise control of strain, strain rate, and heating and cooling rates.

The specimens for metallographic examination were taken from the section of $1 / 4$ depth below the surface. They were mechanically polished and etched in a $4 \%$ nital solution, and then were observed using an optical microscope (OM, LEICA Q550IW, LEICA Microsystems). The average grain size and volume fraction of the DIST ferrite were measured by an image analyzer. To measure the prior AGS, cylindrical samples with a diameter of $6 \mathrm{~mm}$ and a length of $12 \mathrm{~mm}$ were reheated at $1000^{\circ} \mathrm{C}$ for $3 \mathrm{~min}$, and then were water-quenched quickly to room temperature. The austenite grain boundaries were revealed using saturated aqueous picric acid plus $\mathrm{HCl}$ and a wetting agent at 40 to $60^{\circ} \mathrm{C} .{ }^{13)}$ The prior AGSs were measured to be $60 \pm 15,25 \pm 10$, and $55 \pm 10 \mu \mathrm{m}$, respectively for No. 1, No. 2, and No. 3 samples, as also listed in Table 1.

\subsection{DSIT test procedures}

For the present DSIT tests, the specimen geometry with a cylindrical working zone of $12 \mathrm{~mm}$ in length and $6 \mathrm{~mm}$ in diameter was selected, as illustrated in Fig. 1. This relatively complex geometry was applied to meet different requirements for these tests such as heavy deformation and rapid cooling. Due to the constrained geometry of the selected sample design, the strain distribution was not uniform along the axis of the sample. In this study, therefore, the measured strain values are the diametrical ones in the center plane of the specimen where the temperature was recorded using a K-type thermocouple.

The thermomechanical schedule for DSIT tests was shown in Fig. 2. The samples were reheated to $1000^{\circ} \mathrm{C}$ for $3 \mathrm{~min}$ at a constant heating rate of $20^{\circ} \mathrm{C} \mathrm{s}^{-1}$. They were cooled to the desired deformation temperature, $T_{\mathrm{d}}\left(A r_{3}+10 \sim 15^{\circ} \mathrm{C}\right)$, at different cooling rates of 1,5 , and $10^{\circ} \mathrm{C} \mathrm{s}^{-1}$. The samples were held there for $30 \mathrm{~s}$ and then were deformed at a constant

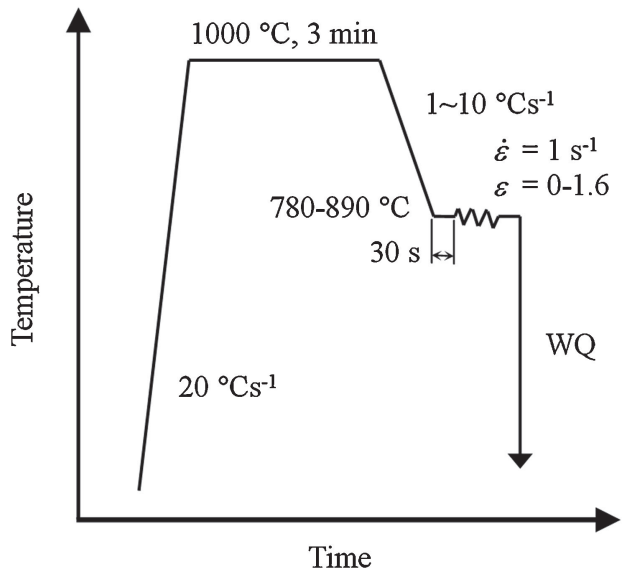

Fig. 2 Thermomechanical schedule for dynamic strain-induced transformation test.

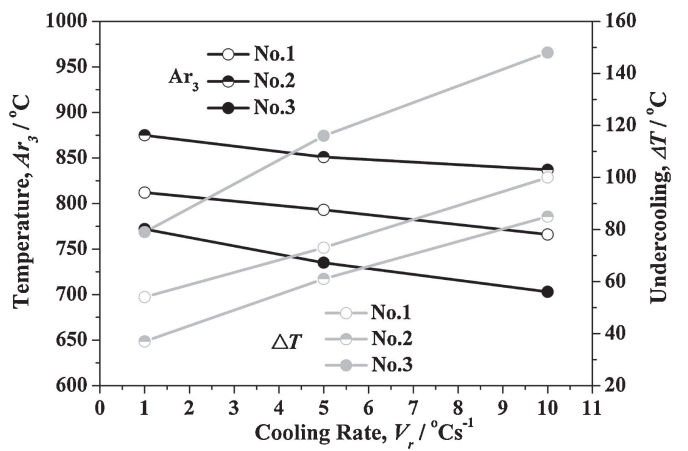

Fig. 3 Changes in measured $A r_{3}$ and $\Delta T$ temperatures with the cooling rate in three low carbon $\mathrm{Si}-\mathrm{Mn}$ steels.

strain rate of $1 \mathrm{~s}^{-1}$ to a prescribed diametrical strain. The $A r_{3}$ were determined from the dilatation-temperature curves measured during continuous cooling. After deformation, the specimens were immediately water-quenched to room temperature. The cooling rate of the specimen surface was estimated to be as high as $400^{\circ} \mathrm{C} \mathrm{s}^{-1}$, which is faster than a critical cooling rate for preventing ferritic transformation during cooling. ${ }^{14)}$

\section{Results and Discussion}

\subsection{Undercooling of austenite}

The undercooling of austenite, $\Delta T$, is defined as the difference between $A e_{3}$ and $A r_{3}$ temperatures. Figure 3 shows the measured $A r_{3}$ and $\Delta T$ as function of the cooling rate in low carbon $\mathrm{Si}-\mathrm{Mn}$ steels. The higher the cooling rate, the higher the undercooling of austenite and the lower $A r_{3}$. The changes in $\mathrm{Ar}_{3}$ with the cooling rate, $\mathrm{Si}$ and $\mathrm{Mn}$ contents have been extensively studied in our previous works. ${ }^{11,15)}$

\subsection{Evolution of flow stress and microstructure during DSIT}

Figure 4 shows typically the flow curve and microstructural evolution of No.1 specimen at $805^{\circ} \mathrm{C}$ with a strain rate of $1 \mathrm{~s}^{-1}$. The cooling rate prior to deformation was $5^{\circ} \mathrm{Cs}^{-1}$, and the measured $\mathrm{Ar}_{3}$ in this case was $793^{\circ} \mathrm{C}$. The shape of the flow curve implies that as the true strain is above 0.2 , a 


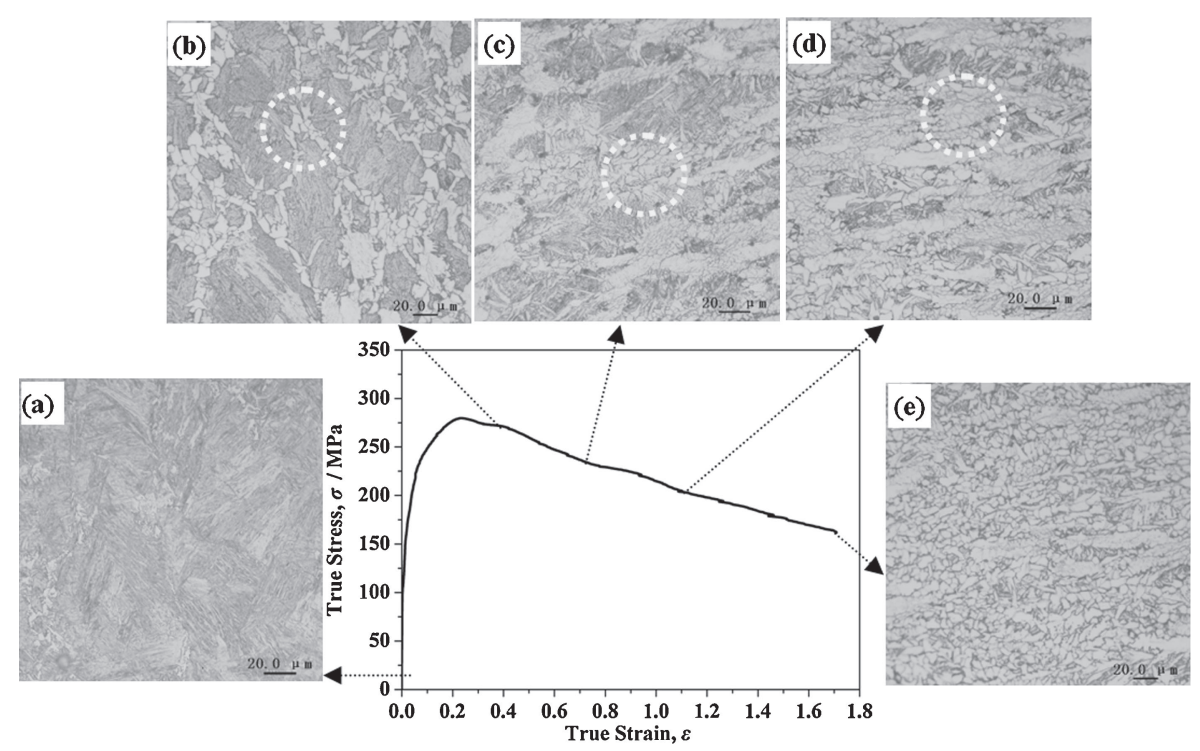

Fig. 4 Flow curve and microstructural evolution of No.1 specimen deformed at $805^{\circ} \mathrm{C}$ with a strain rate of $1 \mathrm{~s}^{-1}$ for different strains: (a) 0.0 , (b) 0.35 , (c) 0.70 , (d) 1.10 , and (e) 1.60 .

certain dynamic softening mechanism took place, releasing the deformation energy in the deformed austenite.

The microstructure of the quenched sample prior to deformation fully consisted of martensite transformed from austenite during quenching (Fig. 4(a)). When the true strain was small $(\varepsilon=0.35)$, the DSIT ferrite was mainly formed along prior austenite grain boundaries (Fig. 4(b)). When the true strain was up to 0.70 , additional nucleation sites were activated inside austenite grains (Fig. 4(c)), probably due to an increase in effective grain boundary areas through cell boundaries, deformation bands, and dislocation arrays. ${ }^{16)}$ With further increasing strain larger than 1.10, DSIT was promoted and ferrite grains with a mean size of approximately 3 to $5 \mu \mathrm{m}$ were continuously formed inside austenite grains (Fig. 4(d) and (e)). Thus, it can be inferred that the type of dynamic softening occurring at the deformation temperature, just above $\mathrm{Ar}_{3}$, was attributed to the DSIT of a hard phase (austenite) to a soft phase (ferrite).

\subsection{DSIT as function of $\Delta T, \mathrm{Si}$ and Mn contents}

Figure 5 shows the flow curves of No.1, No.2, and No.3 samples deformed with a strain rate of $1 \mathrm{~s}^{-1}$ and a true strain of 1.6 at different deformation temperatures. The cooling rates prior to deformation were 1 and $10^{\circ} \mathrm{C} \mathrm{s}^{-1}$ for various $\Delta T$. If the strain or stress exceeded a certain critical value, all the flow curves exhibited the gradually decreased flow stress with strain increment regardless of $\Delta T$, which are similar to the flow curve in Fig. 4.

In view of the DSIT mechanism similar to the dynamic recrystallization (DRX) process, ${ }^{17-19)}$ the critical conditions for DSIT can be achieved like the process of DRX according to the work hardening rate $(\theta) v s$. true stress $(\sigma)$ curves. As shown in Fig. 6(a) and (b), the critical stress for dynamic nucleation of ferrite $\left(\sigma_{\mathrm{c}}\right)$ was determined as an inflection point on the $\theta-\sigma$ curve and the peak stress $\left(\sigma_{\mathrm{p}}\right)$ as a stress where the work hardening rate closely became zero. The measured $\sigma_{\mathrm{c}}$ and $\sigma_{\mathrm{p}}$ values at different cooling rates are summarized in Table 2.

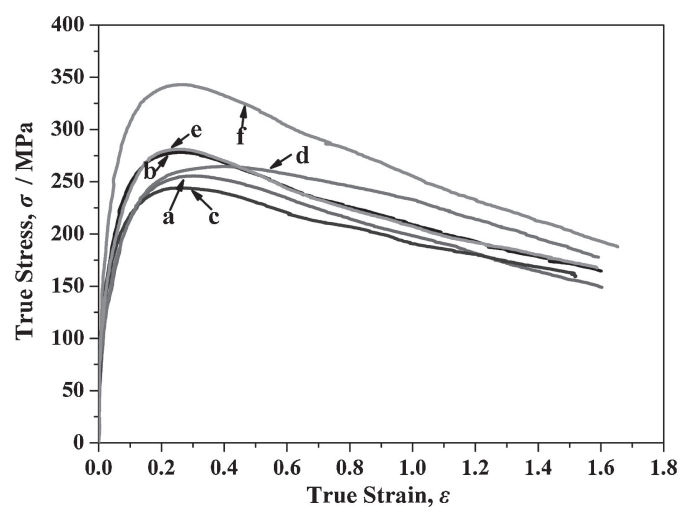

Fig. 5 Flow curves of low carbon Si-Mn steels with a strain rate of $1 \mathrm{~s}^{-1}$ and a strain of 1.6 at the deformation temperature $T_{\mathrm{d}}=A r_{3}+10 \sim 15^{\circ} \mathrm{C}$. (a) No. $1,812^{\circ} \mathrm{C}$, (b) No. $1,766^{\circ} \mathrm{C}$, (c) No.2, $875^{\circ} \mathrm{C}$, (d) No. $2,837^{\circ} \mathrm{C}$, (e) $\mathrm{No} .3,722^{\circ} \mathrm{C}$, (f) $\mathrm{No} .3,703^{\circ} \mathrm{C}$.

Table 2 The critical stress for dynamic ferrite nucleation $\left(\sigma_{\mathrm{c}}\right)$ and the peak stress $\left(\sigma_{\mathrm{p}}\right)$ measured from work hardening rate $v s$. true stress curves.

\begin{tabular}{ccccc}
\hline & \multicolumn{2}{c}{$1 \mathrm{C} \mathrm{s}^{-1}$} & \multicolumn{2}{c}{$10^{\circ} \mathrm{C} \mathrm{s}^{-1}$} \\
\cline { 2 - 5 } & $\sigma_{\mathrm{c}}(\mathrm{MPa})$ & $\sigma_{\mathrm{p}}(\mathrm{MPa})$ & $\sigma_{\mathrm{c}}(\mathrm{MPa})$ & $\sigma_{\mathrm{p}}(\mathrm{MPa})$ \\
\hline No.1 & 240 & 255 & 252 & 278 \\
No.2 & 231 & 244 & 235 & 263 \\
No.3 & 267 & 281 & 317 & 342 \\
\hline
\end{tabular}

As the cooling rate increased from 1 to $10^{\circ} \mathrm{Cs}^{-1}$, both $\sigma_{\mathrm{c}}$ and $\sigma_{\mathrm{p}}$ increased mainly due to the low deformation temperature. The addition of $\mathrm{Si}$ caused slight decreases in both $\sigma_{\mathrm{c}}$ and $\sigma_{\mathrm{p}}$ regardless of $\Delta T$. As shown in Fig. 3 and Table $1, \mathrm{Si}$ increased not only $A r_{3}$, but also the effective nucleation sites at grain boundaries by decreasing the prior AGS, allowing DSIT to happen more easily at a relatively high temperature, and thus decreasing $\sigma_{\mathrm{c}}$. In addition, $\mathrm{Si}$ in solution decreased the plastic deformation capacity of the high-temperature austenite, ${ }^{20,21)}$ leading to an increase in $\sigma_{\mathrm{p}}$. The slight decrease in $\sigma_{\mathrm{p}}$ induced by $\mathrm{Si}$ addition, however, 

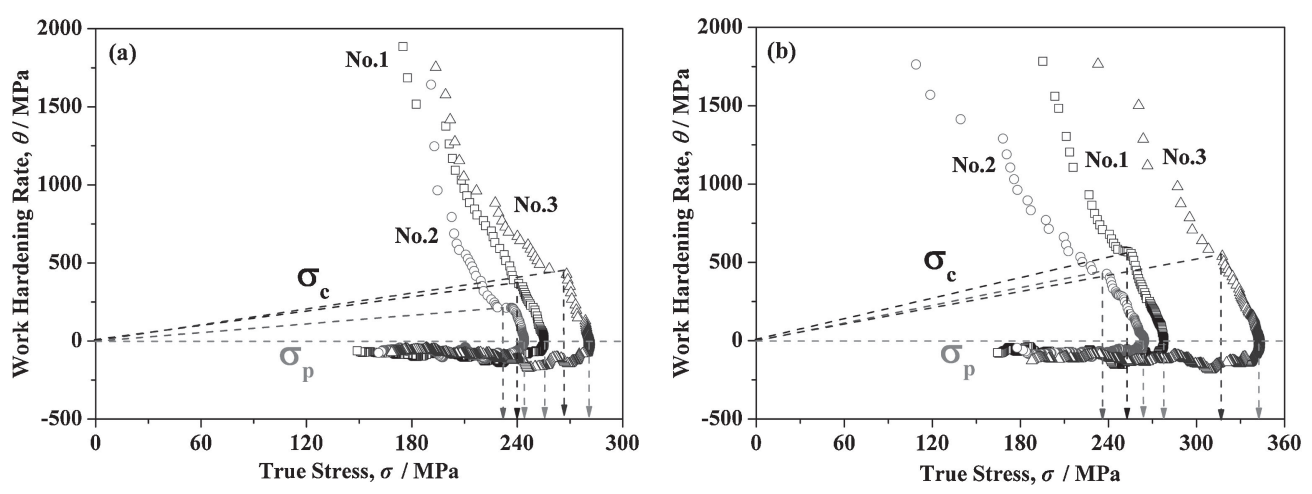

Fig. 6 Determination of the critical stress for dynamic nucleation of ferrite $\left(\sigma_{\mathrm{c}}\right)$ and the peak stress $\left(\sigma_{\mathrm{p}}\right)$ according to the work hardening rate $(\theta) v s$. true stress $(\sigma)$ curves measured at different cooling rates: (a) $1^{\circ} \mathrm{C} \mathrm{s}^{-1}$, and (b) $10^{\circ} \mathrm{C} \mathrm{s}^{-1}$.

indicates that the predominant factor governing the $\sigma_{\mathrm{p}}$ value was the dynamic softening but not the solid solution strengthening at such a relatively high temperature. On the other hand, Mn increased the stability of the undercooled austenite, and prolonged an incubation time for DSIT, ${ }^{22}$ ) which was unfavorable for the proceeding of DSIT and caused an increase in $\sigma_{\mathrm{c}}$, as shown in Table 2. Furthermore, a significant increase in $\sigma_{\mathrm{p}}$ by $\mathrm{Mn}$ addition was attributed to the enhanced solid solution strengthening of the undercooled austenite and the low DSIT temperature.

Figure 7 shows the microstructures of No.1, No.2, and No.3 samples deformed just above $A r_{3}$ at a strain rate of $1 \mathrm{~s}^{-1}$ and true strain of 1.6 for various $\Delta T$. In the case of No.1 sample, the dominant phase was equiaxed ferrite grains at a low $\Delta T\left(54^{\circ} \mathrm{C}\right)$. The average grain size of ferrite was approximately $3.5 \mu \mathrm{m}$ (Fig. 7(a)). Considering the corresponding flow curve shown in Fig. 5(a), the microstructure was produced from the DSIT. With increasing $\Delta T$ to $100^{\circ} \mathrm{C}$, the equiaxed ferrite grains were further refined to $1.4 \mu \mathrm{m}$ (Fig. 7(b)) at a relatively low deformation temperature by imposing a larger $\Delta T$. This resulted in a significant increase in flow stress, as confirmed by the flow curves in Fig. 5(a) and (b). In general, there are two factors affecting the DSIT, i.e., the stored energy produced by deformation leading to the instability of austenite as well as the driving force induced by the degree of undercooling. ${ }^{23)}$ The relatively low-temperature deformation, around $780^{\circ} \mathrm{C}$, led to deformation band structures more easily (Fig. 7(b)), enabling the austenite to store much deformation energy for DSIT. The high stored energy significantly increased the driving force for austenite to ferrite transformation and promoted the formation of finer ferrite grains, as compared with Fig. 7(a) and (b).

The addition of Si made it possible to obtain DSIT ferrite grains at the temperature as high as above $845^{\circ} \mathrm{C}$, which was verified by the flow curves in Fig. 5(c) and (d) as well as the deformed microstructures in Fig. 7(c) and (d). In the case of $1^{\circ} \mathrm{C} \mathrm{s}^{-1}$, No. 2 sample with a relatively high $\mathrm{Si}$ content presented the finer ferrite grains $(2.3 \mu \mathrm{m})$ than No.1 sample $(3.5 \mu \mathrm{m})$, compared Fig. 7(a) with (c). The prior austenite grain size significantly reduced with $\mathrm{Si}$ addition probably due to small degree of superheat, as shown in Table 1. In addition, Si also caused a higher dislocation density and nucleation rate during deformation. ${ }^{10,21)}$ As shown in Fig. 7(a) and (e), the ferrite grain size was significantly

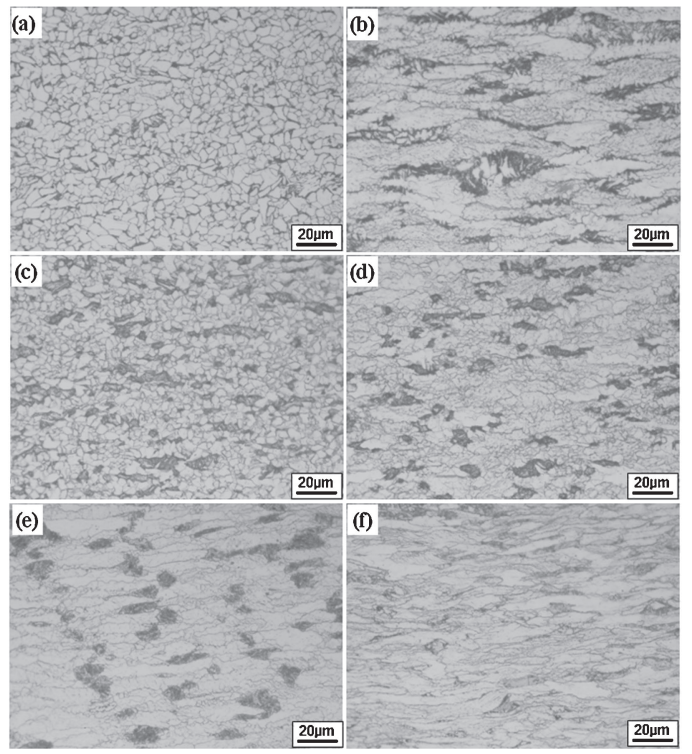

Fig. 7 Optical micrographs of low carbon Si-Mn steels at a strain rate of $1 \mathrm{~s}^{-1}$ and strain of 1.6 at the deformation temperature $T_{\mathrm{d}}=A r_{3}+$ $10 \sim 15^{\circ}$ C. (a) No. $1,812^{\circ} \mathrm{C}$, (b) No. $1,766^{\circ} \mathrm{C}$, (c) No. $2,875^{\circ} \mathrm{C}$, (d) No. 2 , $837^{\circ} \mathrm{C}$, (e) No. $3,722^{\circ} \mathrm{C}$, (f) No. $3,703^{\circ} \mathrm{C}$.

refined to less than $1.5 \mu \mathrm{m}$ with $\mathrm{Mn}$ addition mainly due to the enhanced ferrite nucleation rate and the reduced growth rate, which was accordant with the results reported by Zhou et $a .^{22)}$ It was worth noting that there were no obvious deformation band structures in No.2 steel (Fig. 7(b)) mainly due to a relatively high deformation temperature in high $\mathrm{Si}$ steel as well as easy Mn segregation in high Mn steel (Fig. 7(f)).

\subsection{Effect of $T_{\mathrm{d}}$ on DSIT in high Si steel}

In order to further verify the possibility of DSIT occurring at a relatively higher temperature in the plain low carbon steel with a chemical composition of $0.77 \mathrm{C}-1.35 \mathrm{Si}-0.97 \mathrm{Mn}$ in weight percent, the microstructural characterization and mechanical behavior were analyzed under different deformation temperatures with a strain rate of $1 \mathrm{~s}^{-1}$ and a true strain of 1.1, as shown in Figs. 8 and 9. The cooling rate prior to deformation was $10^{\circ} \mathrm{C} \mathrm{s}^{-1}$. In the case of $800^{\circ} \mathrm{C}$ deformation temperature below $\mathrm{Ar}_{3}\left(\sim 830^{\circ} \mathrm{C}\right)$, ferrite transformation occurred and some amounts of pro-eutectoid ferrite formed 


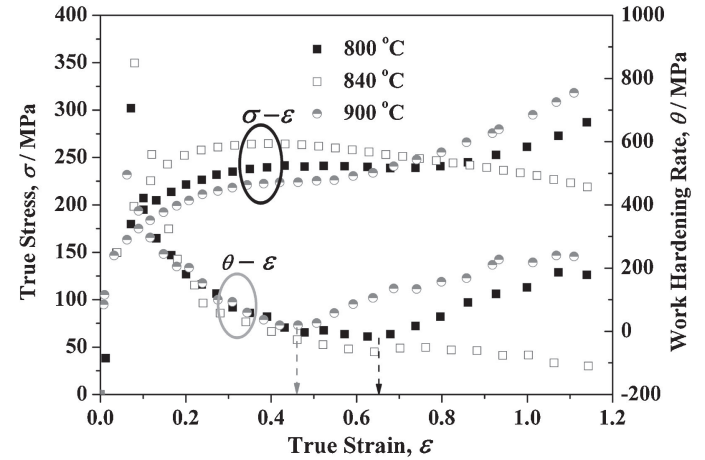

Fig. 8 Changes in true stress and work hardening rate with true strain in high Si $0.077 \mathrm{C}-1.35 \mathrm{Si}-0.97 \mathrm{Mn}$ steel at a strain rate of $1 \mathrm{~s}^{-1}$ and strain of 1.1 under different deformation temperatures.

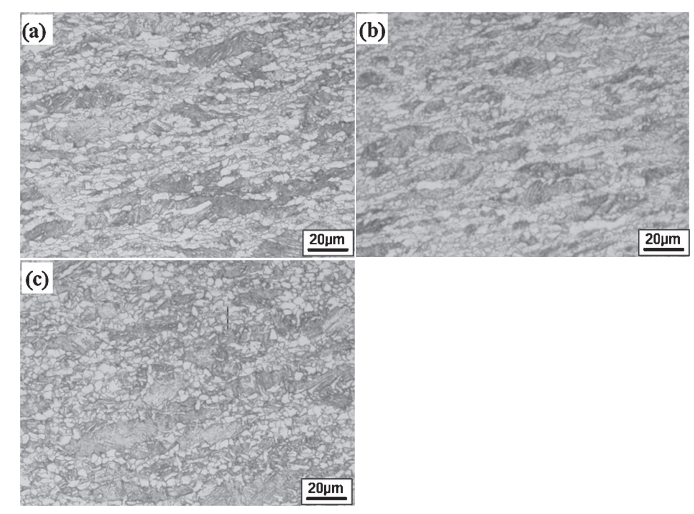

Fig. 9 Microstructural evolution of high Si $0.077 \mathrm{C}-1.35 \mathrm{Si}-0.97 \mathrm{Mn}$ steel at a strain rate of $1 \mathrm{~s}^{-1}$ and strain of 1.1 under various deformation temperatures: (a) $800^{\circ} \mathrm{C}$, (b) $840^{\circ} \mathrm{C}$, (c) $900^{\circ} \mathrm{C}$.

during holding prior to deformation. Furthermore, undercooled austenite easily transformed to ferrite during deformation at small strain levels (e.g. $<0.65)$ because of double driving forces from deformation and undercooling. ${ }^{24)}$ With further increasing strain, the volume fraction of DSIT ferrite gradually reached the equilibrium state, and thus proeutectoid ferrite, untransformed austenite, and DSIT ferrite were further deformed. Therefore, the work hardening rate increased in the later stage of strain, which was partly attributed to the coarse ferrite grains formed during the isothermal holding as well as untransformed austenite. The calculated equilibrium volume fraction of austenite from Thermo-Calc at $800^{\circ} \mathrm{C}$ was approximately $22 \%$, which was in agreement with the measured one $(\sim 19.5 \%)$ from Fig. 9(a). The most important reason why the austenite did not fully transform to ferrite during deformation at such a low deformation temperature may be that high $\mathrm{Si}(1.35 \%)$ and high Mn $(0.97 \%)$ contents in No.3 steel significantly increased the mechanical stability of undercooled austenite.

The flow curve of $840^{\circ} \mathrm{C}$, just above $A r_{3}\left(\sim 830^{\circ} \mathrm{C}\right)$, shows a gradually decreased work hardening rate with strain increment (Fig. 8), implying that a major fraction of finer equiaxed ferrite grains (Fig. 9(b)) were produced during DSIT. The measured volume fraction of DSIT ferrite was about $68.8 \%$, which was similar to its calculated equilibrium volume fraction $(\sim 62 \%)$. It was worth noting that the ferrite grain size achieved in this case was smaller than that at $800^{\circ} \mathrm{C}$, below $\mathrm{Ar}_{3}$. This could be explained that DSIT ferrite could not coarse easily and still remain as fine grains during further straining due to their random orientation distribution. ${ }^{6,25)}$ Therefore, further grain refinement at such a relatively high deformation temperature was attributed to the formation of much more DSIT ferrite grains.

After deformation at $900^{\circ} \mathrm{C}$ much higher than $\mathrm{Ar}_{3}$ $\left(\sim 830^{\circ} \mathrm{C}\right)$, the flow curve in Fig. 8 shows a significantly increased work hardening rate at strain above 0.45 . The calculated equilibrium volume fraction of austenite from Thermo-Calc at $900^{\circ} \mathrm{C}$ was approximately $82 \%$, and the measured one was about $72.3 \%$ (Fig. 9(c)). This indicated that a little amount of ferrite was formed during deformation, and untransformed austenite was dominant even when the specimen was deformed at large strains. Thus, the increased work hardening rate in the later stage mainly resulted from the untransformed austenite.

The DSIT process is more complicated than conventional TMCP process because once transformation starts then the deformation is being applied in the two-phase region. ${ }^{2)}$ However, the DSIT ferrite grains maintained their equiaxed shape along the deformation direction. In previous studies, some thought that DSIT ferrite might undergo continuous dynamic recrystallization resulting in fine and equiaxed grains. ${ }^{6)}$ According to Figs. 9(a) and 9(c), when No.3 steel was deformed at $800^{\circ} \mathrm{C}$ below $\mathrm{Ar}_{3}\left(\sim 830^{\circ} \mathrm{C}\right)$, there were noticeably elongated ferrite grains along the deformation direction (Fig. 9(a)). This indicates that dynamic (continuous) recrystallization of ferrite was not dominant for this case. When the specimen was deformed at $840^{\circ} \mathrm{C}$ just above $\mathrm{Ar}_{3}\left(\sim 830^{\circ} \mathrm{C}\right)$, DSIT ferrite grains mainly maintained their equiaxed morphology, suggesting that dynamic (continuous) recrystallization of ferrite may also be occurring during the DSIT process. Further investigation will be carried out on the misorientation angle of ferrite grain boundary.

\section{Conclusions}

Three low carbon Si-Mn steels were subjected to hot compression tests to investigate the possibility of dynamic strain-induced transformation (DSIT) from austenite to ferrite at a relatively high temperature by using a low carbon Si-added steel.

(1) An increase in $\Delta T$ promoted finer ferrite grains and increased the critical stress levels mainly due to the low deformation temperature.

(2) Regardless of $\Delta T, \mathrm{Si}$ addition slightly decreased both $\sigma_{\mathrm{c}}$ and $\sigma_{\mathrm{p}}$ while $\mathrm{Mn}$ significantly increased both $\sigma_{\mathrm{c}}$ and $\sigma_{\mathrm{p}}$.

(3) Uniform DSIT ferrite grains were produced at a relatively high deformation temperature above $845^{\circ} \mathrm{C}$ using a plain low carbon $\mathrm{Si}$-added steel $(0.077 \mathrm{C}-0.97 \mathrm{Mn}-$ $1.35 \mathrm{Si}$, mass $\%$ ) in connection with a larger $\Delta T$.

(4) For the $0.077 \mathrm{C}-0.97 \mathrm{Mn}-1.35 \mathrm{Si}$ steel, DSIT continuously occurred at $840^{\circ} \mathrm{C}$, just above $A r_{3}\left(\sim 830^{\circ} \mathrm{C}\right)$, causing a decreased work hardening rate $(\theta)$ with strain increment. The $\theta$ value gradually increased at strains above 0.65 (or 0.45 ) at $800^{\circ} \mathrm{C}$ (or $900^{\circ} \mathrm{C}$ ), which was attributed to the work hardening ferrite (or untransformed austenite). 


\section{REFERENCES}

1) P. D. Hodgson, M. R. Hickson and R. K. Gibbs: Scr. Mater. 40 (1999) 1179-1184.

2) Y. Adachi, M. Wakita, H. Beladi and P. D. Hodgson: Acta Mater. 55 (2007) 4925-4934.

3) J. H. Chung, J. K. Park, T. H. Kim, K. H. Kim and S. Y. Ok: Mater. Sci. Eng. A 527 (2010) 5072-5077.

4) M. Shaban, S. Gozalzadeh and B. Eghbali: Mater. Trans. 52 (2011) $8-11$.

5) C. W. Zheng, D. Z. Li, S. P. Lu and Y. Y. Li: Scr. Mater. 58 (2008) 838-841.

6) S. C. Hong, S. H. Lim, K. J. Lee, D. H. Shin and K. S. Lee: ISIJ Int. 43 (2003) 394-399.

7) S. C. Hong, S. H. Lim, H. S. Hong, K. J. Lee, D. H. Shin and K. S. Lee: Mater. Sci. Eng. A 355 (2003) 241-248.

8) B. Eghbali and A. A. Zadeh: Scr. Mater. 53 (2005) 41-45.

9) H. Dong and X. J. Sun: Curr. Opin. Solid State Mater. Sci. 9 (2005) 269-276.

10) M. H. Cai, H. Ding, Y. K. Lee, Z. Y. Tang and J. S. Zhang: ISIJ Int. 51 (2011) 476-481.

11) M. H. Cai, H. Ding, J. S. Zhang, L. Li, X. B. Li and L. X. Du: J. Iron Steel Res. Int. 16 (2009) 55-60.
12) S. Serajzadeh and A. K. Taheri: Mater. Lett. 56 (2002) 984-989.

13) B. L. Bramfitt and A. O. Benscoter: Metallographer's Guide: practice and procedures for iron and steels, (ASM International, Materials Park, Ohio, 2002) p. 305.

14) L. X. Du, C. B. Zhang, H. Ding, X. H. Liu and G. D. Wang: ISIJ Int. 42 (2002) 1119-1124.

15) L. Li, H. Ding, L. X. Du, J. L. Wen, H. M. Song and P. J. Zhang: J. Iron Steel Res. Int. 15 (2008) 51-55.

16) R. Bengochea, B. López and I. Gutierrez: Metall. Mater. Trans. A 29 (1998) 417-426.

17) E. I. Poliak and J. J. Jonas: ISIJ Int. 43 (2003) 684-691.

18) H. Mirzadeh and A. Najafizadeh: Mater. Design 31 (2010) 1174-1179.

19) J. Y. An, Y. J. Kwon, S. I. Kim, D. L. Lee, C. M. Lee, S. K. Hwang and Y. C. Yoo: Mater. Sci. Forum 510-511 (2006) 510-513.

20) S. H. Lee and K. J. Lee: Adv. Mater. Res. 26-28 (2007) 1307-1310.

21) M. H. Cai, H. Ding, J. S. Zhang and L. Li: Acta Metall. Sin. (Engl. Lett.) 22 (2009) 100-109.

22) R. F. Zhou, W. Y. Yang and Z. Q. Sun: Acta Metall. Sin. 40 (2004) 1-7.

23) B. Eghbali and A. A. Zadeh: J. Mater. Proc. Technol. 180 (2006) 44-48.

24) Z. Q. Sun, W. Y. Yang and J. J. Qi: Mater. Sci. Forum 475-479 (2005) 49-54.

25) B. Eghbali and A. A. Zadeh: Scr. Mater. 54 (2006) 1205-1209. 